\title{
The Burden of the Past, the Dialectics of the Present: Notes on Virginia Woolf's and Walter Benjamin's Philosophies of History
}

\author{
Sanja Bahun
}

\section{Preface: On Reading and Writing}

Writing in a Paris rife with war-anxieties, refugees and political plots, a stateless individual by the name of Walter Benjamin recorded on 11 January 1940: "Every line that we succeed in publishing today - given the uncertainty of the future to which we consign it - is a victory wrested from the power of darkness."1 The fusion of desperation and mystical activism in the face of historical horror, expressed in Benjamin's last letter to Gershom Scholem, was echoed across the Channel. Only ten days later, Virginia Woolf - assailed by a mixture of historical, financial, creative and publishing worries - responded to a commission to write about peace by stating that the "views on peace [...] spring from views on war."2 For both Woolf and Benjamin, this anxiety of writingreading (in) history was a corollary of the shared belief that "thinking [was] [their] fighting," as Woolf noted in her Diary, and that the contemporary socio-political situation necessitated an urgent reconfiguration of one's understanding of history, indeed a change in the very telos of historical engagement. ${ }^{3}$ This volatile 'thinking-fight' became a common project for these two intellectuals who never met.

To talk about virtual encounters and hypothesise the results of these exchanges as if they had really happened is always difficult. It is with an amount of apprehension but also conviction that such exercises in possible histories are productive that I embark on the project of establishing the coordinates of Benjamin and Woolf's unrealised dialogue. Aimed at the activation of their thought in association, my enquiry will take the form of a close comparison between Benjamin's and Woolf's last written thoughts on the subject of history - Benjamin's essay 'On the Concept of History' ("Über den Begriff der Geschichte”; this text is familiar to readers in Harry Zohn's rendition as "'Theses on the Philosophy of History") and Woolf's novel Between the Acts. ${ }^{4}$ These texts share not only a moment of production, but also their authors' hesitance to grant them "public life": both texts were published only posthumously and in defiance of their authors' explicit wishes. ${ }^{5}$ To the imagined and real concerns of their authors, the audience, however, responded enthusiastically.

Benjamin's and Woolf's individual philosophies have captured scholarly attention for a long time, but the critical effort to address the intellectual correlations between these two authors has begun only recently. ${ }^{6}$ While the 'Benjaminians' seem to be generally uninterested in Woolf-related scholarship, Benjamin's various conceptualizations of modernity have been recognised as a fertile theoretical support for Woolf studies. It is thus not surprising that the attempts to evaluate the theoretical constellations between the two authors have come mostly from Woolfian quartiers. The site of Benjamin's thought most frequented in Woolf scholarship is the notion of the flâneur, a concept that has proved itself singularly amenable to the analysis of both Woolf's own interest in the philosophy of flânerie and the historical subject constructed in the metropolitan meanderingand-observing activities of her characters. ${ }^{7}$ Complementing these enquiries, the relationship between Benjamin's theory of mass culture and technology and Woolf's writing about, reflecting on, and participating in the culture of technology was addressed in one valuable collection of essays (Caughie 1999), and the correspondences between Benjamin's and Woolf's philosophies of language were treated in an inspired article by Makiko Minow-Pinkney. ${ }^{8}$

The commensurability of Benjamin's and Woolf's philosophies of history, however, has hardly been given proper critical attention. The rare exception is the introductory discussion in MarieLuise Gättens's Women Writers and Fascism: Reconstructing History (1995). ${ }^{9}$ Comparing Benjamin's thought on history to Woolf's cogitation on the gendered aspects of fascism in Three 
Guineas (1938), Gättens perceptively observes that both thinkers link fascist ideology to progressivism and consequently develop structurally comparable challenges to the concept of linear history. Since hers is not a book on either Benjamin or Woolf (or modernist philosophies of history, for that matter), Gättens does not venture further; yet even the mere juxtaposition reveals the Benjamin-Woolf convergence as replete with critical potential. Benjamin's and Woolf's comparable discussions of fascism as both a paradigmatic articulation and a consequence of the linear conception of history are indeed a product of the shared impetus to provide an ethically and existentially grounded critique of the Enlightenment. Yet, one may wish to underscore that this impetus itself is a result of correspondent experiences of history, a shared condition which Benjamin termed "the split structure of experience": an intrinsically anti-linear, if differently gendered and linguistically and culturally rooted, understanding of life and history. ${ }^{10}$ I would like to accentuate the shared structural basis of Benjamin's and Woolf's experiences of history here. In characteristic Benjaminian-Woolfian fashion, this historical experience has more to do with the movement from the "real world" to the "inner experience" (and back) than with either the material world or human interiority independently. An understanding that a movement across the borders of the outer and the interior is a force driving Benjamin's and Woolf's accounts of history allows us to detect what is truly commensurable in Benjamin's and Woolf's thought - the reframing of two major psychological and epistemological practices, interlocked and, as it were, bound to this outward-inward movement: writing and reading.

The recognition of the persistence of this outward-inward movement in Benjamin and Woolf may also help us understand another authorial trait which these two thinkers share: their continuous dissatisfaction with the proposed models of history, including those proposed by themselves. For neither Benjamin nor Woolf seem to stop at the critique of linear history; rather than unequivocally espousing alternative models, for example, circular history or fragmented (intermittent) history, Benjamin and Woolf continually probe the practices of reading and writing history, questioning, indeed, the viability of any fact-based conceptualisation. In turn, they constantly refine their own conceptualisation of history. What I suggest here is that, taken in sum, Benjamin and Woolf's critiques of the traditional concept of history are at the same time more socially radical and more theoretically problematic than is usually perceived: they entail the questioning of consistency of facts as a judicious requirement for any conceptualisation. For all the danger of inefficacy (of which both Benjamin's and Woolf's respective philosophies of history have been accused), this questioning is highly relevant for everyday social practice. Thus I will open this study by a methodological caveat: to actualize the socio-political potential of Benjamin's and Woolf's thought on history, one has to accept history in their writings not as a metaphor or a critical trope but as a distinctive engagement with the material world, as a living dialectics that may offer tangible means of reflecting on and working in history: the transformation of the practices of acquiring and recording knowledge. The present article is premised on such an interpretation.

\section{Convergences}

That the potential link between Benjamin's and Woolf's philosophies of history has received scant critical attention is not surprising; the idea of comparative work exploring artists and philosophers of history still rings false. With respect to these two authors in particular, the empirical evidence confirming the possibility of mutual influence is still lacking, and interested scholars naturally feel uncomfortable with overly general correspondences. Yet it is reasonable to conclude that Benjamin might have at least heard about Woolf and her fiction by 1939-1940. One may take the following as the sensible indicators of Woolf's growing reputation in France from 1927 to 1940: Jacques-Émile Blanche’s introductory article on Woolf in Les nouvelles littéraires (13 Aug 1927), accompanied by the French translation of Woolf's short story "Kew Gardens" and the first passages of To the Lighthouse; the publication of Mrs. Dalloway in French in 1929 (with the preface written by André Maurois); the publication of Floris Delattre's book-length study Le Roman psychologique de V. Woolf (1932); and Marguerite Yourcenar's famous translation of The Waves in $1937 .{ }^{11}$ Finally, Woolf was also closely attached to the French cultural scene by both 
personal proclivities and an extended circle of acquaintances which included female literati such as Sylvia Beach and Adrienne Monnier, both close friends and supporters of Benjamin. ${ }^{12}$ Significantly, Beach and Monnier also provided Benjamin with English and American literature in the late 1930s, a period that saw an increase in the his interest in the English language and Anglophone creative writing (SW, 441).

On the other hand, Woolf may have been acquainted with or, even more, engaged in the contemporary German philosophical and literary scene in a more direct way - via her associations with the young Bloomsbury generation, namely, W. H. Auden, Christopher Isherwood and Stephen Spender, and Beatrix and John Lehmann (the managing director of the Hogarth Press 1938-46), all of whom intermittently participated in Berlin cultural life in the late 1920s and early 1930s. The complex yet stimulating task of tracing the association between German and British inter-war philosophies of history has to revolve around the (potential) link between these young intellectuals and Bertolt Brecht, whose own political aesthetic was, in turn, much influenced by his collaboration and friendship with Benjamin from 1929 onwards. Auden's presence at the first production of Bertolt Brecht's and Kurt Weill's The Threepenny Opera (in autumn 1928) seems to have been one of the formative experiences not only for the poet himself but for an entire generation, including those who participated in that vigour indirectly, as Woolf $\operatorname{did}^{13}$ Auden's first stay in Berlin and his timid participation in its intellectual life also coincided with the period in which Brecht's and Benjamin's friendship intensified and their tense intellectual collaboration started: it is in the context of their dynamic plans for a new critical journal dedicated to literature, philosophy, and political science that Benjamin's early philosophy of history was forged. ${ }^{14}$ All these intellectual encounters matured and transformed in the 1930s into a complex network of mutually invigorating "artistic" philosophies of history, a constellation that still waits to be critically addressed. The present essay is dedicated to one such convergence: Benjamin's and Woolf's final thoughts on history.

Benjamin's essay "On the Concept of History”, completed in late April or early May 1940, comprises eighteen theses on the concept of history (perhaps followed by two sections headed by capital letters $\mathrm{A}$ and $\mathrm{B}){ }^{15}$ The theses are organized by the opposition of two models of historiography: one, referred to as "historicism", which subsumes the flaws of all kinds of the then operative historiography and which finds a political counterpart in the German Social Democratic Party; the other, called "historical materialism", which offers a set of alternatives to the normative models of archiving, selection, reference, and interpretation of historical data. The theses engage various, sometimes incompatible, intellectual and activist currents in philosophy of history, and propose a combustive fusion of theology and Marxism as a solution to the conundrums of history. ${ }^{16}$ The result is a twofold critique: a critical assessment of the traditional historiography as a practice based on empathy with historical victors, and the critique of the conceptualisation of history which is rooted in the notion of humankind's unbound progress. While the essay could be understood as an end-product of almost twenty years of Benjamin's reflection on the content and practice of history, Benjamin confided to a number of correspondents that the text had been specifically motivated by what he perceived to be the common experience of his generation in the years leading to the Second World War. ${ }^{17}$

Like Benjamin, Woolf admits that her last novel, Between the Acts, is marked by the general feeling of "the doom of sudden death hanging over." ${ }^{18}$ Compressed within the course of twentyfour hours of a June day in 1939, Between the Acts delineates its narrative space against the background of "the gun slayers, bomb droppers" at the beginning of the Second World War (BTA, 187). Yet, within this moment of extended stasis, between the acts, several things happen and the narrative, analogically linked to history, moves simultaneously in circles and increments: a family undergoes a subtly intoned crisis and an ambitious village pageant is performed on the family grounds despite the vagaries of the summer weather; the pageant is a symbolist-ritualist-Brechtian exercise that aspires to present nothing less than English history in its entirety (as well as the history of English literature). As the day progresses, the agents of the private world and general history are revealed as comparable, and the family house emerges as a privileged synergic point for the performance of personal and socio-historical agons. This series of narrative moves unearths gaps in official, private, and literary histories, and effectively underscores the inadequacy of the operative models of recording history. 
What connects these two generically different cogitations on contemporary and general history and the practice of its record? Part of the answer lies in the exact contemporaneity of the two texts and, consequently, in the similarity of possible "real world incentives" which are easy to intuit. As becomes evident early in the texts, both Benjamin's and Woolf's specific target in their last writings is the ineffectiveness of the global response to the rise of fascism. Benjamin emphasizes that "the current amazement that the things we are experiencing are 'still' possible in the twentieth century is not philosophical” (“Concept”, 391), and he finds an exemplar of this ineffectual 'amazement' in the behaviour of the German Social Democratic Party. Woolf, on the other hand, distributes the question of what would be an effective or ineffective response to the current history among many characters in Between the Acts; the issue of historical engagement torments not only Giles, but also every major and minor character, including the ghostly narrator herself.

More generally, however, Benjamin's vision of the past and the present united in the moment of danger speaks well to Woolf's artistic and political project in Between the Acts - to write the world/human life in a moment of crisis. Yet this project is also characteristic of a general modernist philosophical-historical sentiment of the late 1930s, and it should be noted, that, to a certain extent, Benjamin's and Woolf's critiques of normative historiography can be viewed as the more or less typical intellectual fruits of their time. Their philosophies of history consist of a stock of modernist conceptual tropes: anti-progressivism, critique of Enlightenment, interaction of theory and practice (after Benedetto Croce), and, as Heinz-Dieter Kittsteiner has noted with regard to Benjamin, the discourse of "a rather conservative critique of civilization which became amalgamated in the 1920s and the 1930s with the position of the 'Left'."19 Furthermore, both authors are mindful of the narrative character of the historical record, and, similarly to the early conceptualisations of the Annales School, attentive to (urban) geography, material culture, and group psychology; the last is particularly characteristic of Woolf's mature writing. Like many contemporaneous philosophers of history (and the Cambridge friends of the Stevens), Benjamin and Woolf reject G. W. F. Hegel's teleological model of history as the realization of the idea of freedom; thus their conception of history gives expression to the demise of progressive linear sequence, i.e., narrative, which was much in evidence in the thought and creative writing of the period. Similarly to many other modernist thinkers and creative writers, Benjamin and Woolf use myth as a structural lever for their critique of linearity. Furthermore, both thinkers have made precarious attempts to "deteleologize" some alternative ontologies (theology and pantheism, respectively). Finally, much of Virginia Woolf's mature creative work and almost the entire oeuvre of Walter Benjamin may be understood in the context of cultural history, the then nascent discipline in which Benjamin was educated (which was much in prominence in the circle of the Cambridge Apostles) and within which and against which Benjamin and Woolf must have formulated their major insights. ${ }^{20}$ Yet to each of these lines of inquiry, Benjamin and Woolf offered their own methodological correctives, fusing and moulding concepts without worrying too much about hermeneutical inconsistencies, but taking an extraordinary interest in the form of their own cogitations. And this is the point which I would like to elucidate further.

For, as will become apparent, one of the decisive factors in my choice to correlate these two writings has been the profound, if occluded, structural and discursive similarity of Benjamin's and Woolf's texts. This commensurability across textual forms (the genre of 'theses' and the genre of the novel, respectively) exteriorises a number of similarities in the authors' perception, evaluation, and rendition of history. The structural correspondence of Benjamin's and Woolf's last writings is thus the function of the shared subject-matter: how to write history. Or, more precisely: how writing about or narrating history can be liberated from the entanglement in the discursive dominance of victors, rulers, and their heirs ("Concept”, 391). What these "swan's songs" of two exemplary modernists propose by their content-made-form is a questioning or dereifying of reading-writing practice. Such a dereifying practice should be recognized as one of the most significant modi of 'working in history', indeed the only possible way to generate transformation in history, Benjamin's and Woolf's writings propose. In the following pages, I will examine the major properties of this practice. 


\section{The Way of History: Lines, Circles, and Other Forms of Record}

Speaking from a great historical watershed, both Benjamin and Woolf define the practice of writing and working in history as inextricably bound to the question of how one perceives the relation between the past, the present, and the future. For both thinkers, the greatest danger for our understanding of history resides in the customary espousal of linearity, a form of temporal hegemony to which we are prone and by which we unwittingly become a tool of the dominant. Let us, then, first spell out what it means to become an instrument in this game: it is to subscribe to a notion of universal history unfolding progressively in homogenous and empty time, which produces what we retrospectively "recognize" as a layering of cultural and historical products: "Babylon, Nineveh, Clytemnestra, Agamemnon, Troy” (BTA, 140) - Woolf is poignantly selective in her choice of historical "wreckages" which an honest historian cannot contemplate without horror (SW, <Paralipomena to "On the Concept of History”>, 406-407). Benjamin argues that the self-perpetuating association of the notions of universal history, progress, and culture, presents the most detrimental aspect of our reflection on, experience of, and work in history. Woolf follows Benjamin closely in two of these critiques, that of the notion of progress and that of universal history unfolding in homogenous time (she has a different and more complicated take on culture, though). Drawing our attention to the use of similar figures of speech, Marie-Luise Gättens has emphasized that Woolf's "procession of the sons of educated men" in Three Guineas and Benjamin's "the triumphal procession" in 'On the Concept of History' both point to "the connection between progress, a notion of history as unfolding in linear time, and the violence that accompanies it” (Gättens, 32). But we can find the subversion of linearity and progressivism more vividly represented in the fragmentation and dissipation of all the 'processions' in Woolf's Between the Acts, from the line of villagers passing in and out of the stage during Miss La Trobe's pageant, to the scattered spectators, to the dramatic form which is given to Miss La Trobe's pageant and the novel itself. As it appears in Benjamin's and Woolf's writings, then, the threefold critique of linear progression - the critique which is both expositional and formal - presents a sophisticated corrective not only to traditional philosophies of history, but also to those by Hegel and Marx.

It is instructive, however, to take a closer look at this critique. At first sight, it might seem that Benjamin and Woolf counter Enlightenment progressivism by the familiar modernist experimentation with cyclicity. Their critique does partake of the same rebellion, but it differs from the simple negation of linear unfolding of history by superimposition of a mythical cycle. As frequently noticed by Woolf scholars, the writer's seemingly 'cyclical constructions' are never self-identical; ${ }^{21}$ likewise, Benjamin criticizes the eternity of a cycle on a few occasions, most explicitly in his <Paralipomena to "On the Concept of History">. Indeed, one may argue that Woolf and Benjamin are not so much against linearity as they are against the exultation of 'homogeneity' of history and of vulgar progressivism which find its expression in linear narration. On some occasions, it also appears that neither of the two thinkers is against the notion of universal history per se, but only against its positioning in homogenous time-and-space without a constructive (or aesthetic) principle to move it, disrupt it, explode it. This contradictory critical potential comes from the fundamental hermeneutic instability of both Benjamin's and Woolf's philosophy of history: their reflections vacillate between the different proposed and rejected models of history (spiral, linear, cyclical history, history of events, intermittent history, and so on), and, at times, adopt a genuine espousal of one, none or some of these models. The unifying factor in these volatile conceptualisations of history is the belief that " 'the state of emergency' in which we live is not the exception but the rule" ("Concept", 392) and that this condition demands a constant reconfiguration of our perception of and practice in history.

As I have mentioned, it is primarily in the relation of the three aspects of time as shot through by the socio-political moment of "the now of recognizability" (SW, "Paralipomena", 405) that Benjamin's and Woolf's philosophies of history are commensurate. The shared concern is the product of a more general tendency in the philosophy of history and historiography of the time, one that aptly conjoins German and Anglophone intellectual spaces: presentism. Articulated by thinkers such as Wilhelm Dilthey, R. G. Collingwood, and Michael Oakeshott, and much discussed in Cambridge at the turn of the century, presentism dispels the notion that one can 
address the past independently of the present. On the contrary: it is only through/from the present that we understand the past, and, as such, the past has to interrelate with the present. For both Benjamin and Woolf, this insight is vital, for it allows them to think of the relation between different time planes in non-linear terms. ${ }^{22}$ Yet neither Benjamin nor Woolf accepts this doctrine uncritically. In fact, in Theses VI-VII Benjamin explicitly denounces the basic premise of presentism: the belief that it is possible to record history "the way it really was" (Leopold von Ranke) by empathizing with the past events (in the tracks of Wilhelm Dilthey and Friedrich Schleiermacher). The "fake innocence" of this position is belied by the fact that the historian's "empathy" (Einfühlung) is always empathy with the side victorious in historical dynamics ('Concept', 391). Benjamin is vocal in his admonition that the attempt to "relive" an era is necessarily conducted with the help of artefacts, preserved "cultural treasures", which are invariably the choice of socio-political and cultural victors ("Concept", 391). For Woolf (or Woolf-as-philosopher-of-history) however, this wariness of empathy is new; it may very well be that Between the Acts is the only novel where this suspicion is discursively and performatively articulated. Unlike Sabine Hotho-Jones, who grounds Woolf's thought on history firmly in the doctrine and practice of presentism, I would argue that Woolf - at least the Woolf of Between the Acts - was deeply aware of the hegemony of the history-writing subject inherent in this doctrine. It is with much ironic distance and marked, indeed Brechtian, alienation effects that we observe the unfolding of British history in Miss La Trobe's play. Replete with gaps, diverse rhythms, and short cuts, this history is, importantly, presented by an unlikely set of actors - an idiot, a tobacco-seller, a young shop assistant, a cowman, and others - whose mundane life compellingly and humorously deconstructs the history presented on the stage. Evidently, Woolf shares Benjamin's belief that to write or perform history truthfully does not mean to recognize and record the past events as they "really" happened, to "resurrect", "relive" them, or even to narrate them in traditional terms. Rather, she might agree with the German thinker that the effort narratively to re-member history entails getting involved with a pile of wreckages.

\section{(Im)possible Histories}

Benjamin's and Woolf's shared denouncement of traditional historiography is, therefore, premised upon two critical propositions. First, the validity of the inherited historical record is dubious: there are more and more varied histories than we have accounted for. Secondly, the attempt to represent the past events as they 'really happened' as well as the process of empathy by which traditional historiography lays its claims to truth are essentially hegemonic practices. These two critiques of traditional history-writing can be translated into two fundamental questions pertaining to "new writing of history": Who/what should be the subject of historical knowledge? How should that knowledge be rendered?

For Benjamin, the new historiographer should "brush history against the grain" and salvage the object of historical inquiry from the realm of the obscured and the vanquished ("Concept", 392). But this realm of the obscured, rendered through the broadly conceived category of "the anonymous" (<Paralipomena>, 406), is wider than one might expect at first. In his commentary on Thesis VII, Adorno underscores the importance of the activity of "brushing against the grain”, but he also points out a specific intervention in epistemology and methodology of historical research that such a move implies:

If Benjamin said that history had hitherto been written from the standpoint of the victor, and needed to be written from that of the vanquished, we might add that knowledge must indeed present the fatally rectilinear succession of victory and defeat, but should also address itself to those things which were not embraced by this dynamic, which fell by the wayside - what might be called the waste products and blind spots that have escaped the dialectic. It is in the nature of the defeated to appear, in their impotence, irrelevant, eccentric, derisory (. . .) Theory must deal with cross-grained, opaque, unassimilated material . . . ${ }^{23}$ 
Benjamin's writings speak well to Adorno's advice: their regular subject is the fleeting contents of history's underside: Germany's unemployed; the protestant lamentation play in the context of the exuberance of the catholic Baroque; bohemians and flâneurs of the Second Empire; children; the avant-gardists of the 1930s; temporally displaced story-tellers; the mentally ill; gamblers; old toys; city-streets; pornography; "absent presences” such as shadows and angels; and, also, as Beatrice Hanssen has recently suggested, a variety of natural world occurrences - wild and domestic animals, stones, and dual-species creatures such as those found in Franz Kafka's writings. $^{24}$ This (seemingly) impotent, eccentric and ex-centric material presents the subject-core of Benjamin's enquiries; it constitutes a dynamic philosophy of history dedicated to what Rodolphe Gasché has called a "radical and non-phenomenal Other.”,25

Virginia Woolf agrees with Benjamin that it is "the struggling, oppressed class itself" or "the anonymous" that should be the subject of historical interrogation ("Concept”, 394). Indeed, already in 1925 Woolf sketched the project of revealing the unrecognized or unassimilated material of history. In her Diary, Woolf records that she would like to devote her writing efforts to the depiction of the "Lives of the Obscure - which is to tell the whole history of England in one obscure life after another." ${ }^{26}$ Whereas this project informs the entirety of Woolf's oeuvre, Between the Acts is still a specific case: the voiceless individual that is in the centre of Woolf's attention in this novel does not speak exclusively in a female voice as in some other writings; rather, the narrative of Between the Acts is based on the proliferation of different phenomenal and nonphenomenal Others. The search for the unrecorded and the unheard vigorously shapes the novel: the inflection of the main narration by multiple outsider-insider mini narratives serves precisely this social and artistic purpose. The novel abounds with different small personal (hi)stories narratively competing for our attention - those of visitors, nurses, servants, passers by, birds, ghosts, even immobile objects. These minute attempts at narrative empowering open up the vista of unseen histories and install a polyphonic structure of rare complexity. The function of this polyphony is commensurate with Benjamin's advice for the chronicler to "[narrate] events without distinguishing between major and minor ones" so that she "acts in accord with the following truth: nothing that has ever happened should be regarded as lost to history" ("Concept”, 390).

Out of this overarching examination of the three aspects of time as they become visible in "the now of recognizability", one distinctive vision of history emerges for Woolf of Between the Acts: what profiles history is the dynamics of agon and stasis. Woolf's novel starts in Benjaminean fashion: the moment of danger (war) discloses the agonic nature of history for the small party discussing the future site for the cesspool; it impels the past to rush forth into the present, to fuse the scars of the Romans on the road chosen for the cesspool with those inscribed by the Second World War. Woolf closes Between the Acts with a comparable postulation of the agonic basis of history: ". . . first they must fight, as the dog fox fights with the vixen, in the heart of darkness, in the fields of night" (BTA, 219). The latter passage, however, reveals that antagonism is also the basic principle of love. In order for a new life to emerge, for a personal story to unfold into genealogy, one first has to struggle: "Before they slept, they must fight: after they had fought, they would embrace. From that embrace another life might be born” (219). Thus, for Woolf, agon presents itself as an overarching principle conjoining different planes of human interaction, love as well as hate. The idea of a parallel series of agonic histories is also an intrinsic component of Benjamin's Marxist analysis of society. But it is the human perseverance in this unfolding of historical agons and stases that gets the most poetic and most poignant treatment in both Woolf's and Benjamin's accounts of history. Patiently stumbling, the (symbolically gendered) donkey in caravanserai will "go [its] way till [its] heels blister and [its] hoofs crack” (BTA, 155). Benjamin's "Angel of History" would like to remain in the moment of stasis, to "awaken the dead, and make whole what has been smashed" ("Concept”, 392), but his flight into the future, propelled by the inexorable storm called 'progress', is as inevitable as the burdensome voyage of Woolf's little donkey. The machine of history 'chuffs' on and the observant can only capture it at the moment of constellation, a content-filled or vacuous suspension of movement. Such is the practice of "true historians”, Benjamin relates.

In order to circumvent the hegemony of the historical record and recover the hidden histories of perseverance, Benjamin's and Woolf's critiques partly restore to history what Benjamin claims to be its original role as remembrance or memoration [Eingedenken] (<Paralipomena $>, 401){ }^{27}$ 
Wrought by the tension between activism and lamentation, this conception of history resignifies the notion of remembrance as not the past-made-present, but the past-that-implicates-the present. ${ }^{28}$ This approach is premised upon the postulation of radical incompleteness for the past, a crosstemporality which is hardly understood, let alone co-opted, by mainstream historiography. The methodological problems are amplified by the "modernist" requirement for this memorial practice: to avoid the subjugation of the past to the present, memoration has to be spontaneous. Thus a "true historian' should articulate history through the discursive appropriation of an involuntary memory as it "flashes up" to the present and onward into the future "in a moment of danger", Benjamin advises ("Concept", 391).

The narrative of Woolf's Between the Acts centres on just such a memorative practice: Miss La Trobe's pageant. As the mirror-reflection scene, the final act in Miss La Trobe's examination of the "unity-disparity" of the historical subject, confirms, the pageant is a conscious artistic effort to (com)memorate the past as it relates to the present. Reinforcing the act of memoration as the dynamic principle of the historian's work, this performative get-together moves beyond a mere resurrection of selected moments in past. As articulated in Miss La Trobe's play, Woolfian history does not simply unfold; it interrelates. The performed historical fragments thus forge their "truthvalue" through an interrelation with other (fictional) texts: history of literature and general history conflate in the pageant. At the same time, this complex history-text interacts with an unlikely cast (villagers), their mundane occupations and their personal histories. This already complicated "history" is further inflected by a variety of reactions in the audience: juxtaposing the public and private memory, the reception (both the approval and, as the play advances, confusion felt in the audience) puts forward an alternative picture of the historical times under interrogation. While these multi-directional links constantly reconfigure the historical narrative into inconclusiveness, the central thrust of Woolf's critique lies, however, elsewhere: the strategic distribution of static moments in the text installs an even more radical practice of "knowing history". For, as Miss La Trobe intuits, memoration is least effective when it progresses smoothly and voluntarily. It is only when this evolutionary movement is suspended and the voluntary memory is challenged that the joining of the public/general and the private/individual histories succeeds in the novel. It is thus in shortcuts, interruptions, and (unintentional) disruptions of temporal logic - indeed, between the acts - that we should seek traces of the hidden dynamics of history, Woolf's textual practice indicates.

In such moments the series of agons ceases, and the agonic activity both surpasses and annihilates itself. In one famous intermission scene, Giles takes account of his personal failures and possibilities by playing a game of "mental soccer". Arriving at the imaginary "goal”, Giles discovers a curled snake, choked with a toad in its mouth. Caught in the midst of movement, the snake and the frog have come to a stasis: "The snake was unable to swallow; the toad was unable to die. A spasm made the ribs contract; blood oozed. It was birth the wrong way round - a monstrous inversion" (BTA, 99). This "frozen image” displays in unsparing light the subjectnegating contradiction which lies at the heart of the human working in history. The selfreproductive, hate-, love-, and birth-giving agons have led to a stasis; nothing could be gained, no one has won in this war-game: this is an abortive action, a "birth the wrong way round." 29 The potency of this image comes from the representational surprise it holds in store for the viewer/reader: our active, agonic history is congealed in the absurd state in which Giles finds the snake and the toad. It is by revealing an impasse, a stagnant gridlock, behind historical and natural struggles that Woolf's moment of stasis exposes the 'monstrosity' of history.

The illuminatory nature of arrested images and action-paralyses in the text affiliates Woolf's use of stasis with Benjamin's notion of the "standstill” (Stillstellung), a static instant in which the past and the present converge and disclose the real dialectic nature of history ("Concept", 396). This is a plausible association, since Woolf emphasizes the revelatory potential of standstills in the narrative. In particular, Miss La Trobe's experimentation with dramatic stasis is aimed at provoking such moments of revelation. In the outline of her pageant, Miss La Trobe envisions the strategic use of stasis: “'After Vic., [. . .] try ten mins. of present time. Swallows, cows, etc.' She wanted to expose them, as it were, to douche them, with present-time reality” (BTA, 179). This is an example of deliberate dramatic stasis, intended to give Miss La Trobe's audience a chance to perceive themselves in history and in the present historical moment, as the narrator confirms. Such 
experimentation should be understood as a Benjaminian-Brechtian exercise. Yet, unlike Benjamin (as well as Brecht), for whom the moments of stasis present a "revolutionary chance" ("Concept", 396), Woolf does not always conceive of them in celebratory terms. For her, the disclosure of historical dynamics in the moment of stasis always entails a risk. Precisely because of the intensive despair which accompanies such a revelation, one is prone to fall into autistic stillness, to be driven into ahistorical escape. The image of the snake choking with a toad in its mouth is so disturbing that it resides at the very verge of the representational plane. Much as it can raise awareness of a particular moment in history, it may also lead to meaninglessness, to the overwhelming feeling of absurdity that empties out our command of metaphor. The last is indeed Giles's reaction to the war (BTA, 53).

Here we may observe an important difference between Benjamin's proposal of an active coalescence of the past and the present to produce the future and Woolf's insistence that the true understanding of historical dynamics is granted only to "an engaged spectator", or, better still, an engaged abstinent from historical dynamics. Whereas both Benjamin and Woolf relate the moment of stasis to an encounter with the superhistorical time of the dead (the Angel of History wants to "awaken the dead" ("Concept", 392); suffering the dramatic stasis together with her audience, Miss La Trobe notes, "This is death, death, death” (BTA, 180)), this revelatory event implies different levels and types of action for the two thinkers. For Benjamin, the suprahistorical stasis is a moment to act historically, a moment for political revolution; for Woolf, the revelatory stasis is a suprahistorical moment of annihilating action, of touching death - and, together with it, the artistic and mythmaking essence of life. Woolf conceives of death, as Ann Banfield has astutely observed, as a point of separation between the (transitory) self and the (ongoing) material world, where it is the property of the subject, however, to try to reflect on and aesthetically describe both this separation and the (possible) continued life of the material world irrespective of the subject. ${ }^{30}$ This vision of death, I would argue, strongly influenced Woolf's interpretation of historical engagement, especially in the period of writing Three Guineas and Between the Acts, at the time when she was trying to find an aesthetic means to render both "these rather abstract words and these very positive photographs - the photographs of dead bodies and ruined houses." ${ }^{31}$ To engage with history from the liminal position of the subject trying to envision the world without itself means to perceive historical dynamics (or, more problematically perhaps, historical transformation) as possible without our physical presence, and yet as somehow consequential upon our present activity. This paradoxical vision of historical practice finds its expression in Woolf's enduring belief in the paradigmatic 'engaged abstinent' - the artist - and his/her distinctive modus of "fight" - writing.

Woolf's redefinition of the concept of social engagement is, however, indicative of the complexity of the issues at hand and also of the guarded optimism of these new conceptualisations. For this whole "fight for the oppressed past" ("Concept", 396), political and artistic, has an index to impossibility woven into the very texture of both Woolf’s and Benjamin's projects of writing history. By a deliberate and almost forceful artistic move, Woolf frequently cuts short the subnarratives in Between the Acts - mostly through a strategic use of ellipses. Significantly, Woolf forever extracts parts of the peasants' song in Miss La Trobe's pageant, a song which narrates the peasants' own 'toil' of history:

Cutting the roads ... up to the hill top ... . we climbed. Down in the valley. . . sow, wild boar, hog, rhinoceros, reindeer. . . Dug ourselves in to the hill top . . . Ground roots between stones . . . Ground corn ... till we too . . lay under $g-r-0-u-n-d$. . (BTA, 78)

These interventions produce the effect of narrative "short-circuits" induced by an authorial/authoritarian power. The punctuation of gaps and omissions artistically corresponds to social dynamics as seen by Woolf: the universal whole of history is replete with holes. The only way to approach these obscured histories is, then, to cite their gaps in their irretrievability. Woolf's final and most radical probing of the possibilities of writing alternative history(ies) is a sore celebration. 
The need for the citability of all the obscured moments of past history presents a problem for Benjamin, too. In a theoretical loophole, Benjamin goes on to argue that only a "redeemed mankind may be granted the fullness of its past - which is to say, only for a redeemed mankind has its past become citable in all its moments" ("Concept", 390). For Woolf, however, the past does not ostensibly "[carry] with it a secret index by which it is referred to redemption" (390); neither does she ostensibly entertain the theme of redemption in Between the Acts; "ostensibly", I say, for the sympathetic treatment of the character of Lucy indicates that Woolf's philosophy of history is also, if almost imperceptibly, interspersed by an intimate theology. One may discern this parallel ontological structuring of history in the sudden and often unprepared introductions of pantheism in the novel. It is precisely the vanishing of the peasants' song that also affirms the existence of a force that surpasses even those narratively empowered: the wind, we are told, can make even the great names inaudible:

The words died away. Only a few great names - Babylon, Nineveh, Clytemnestra, Agamemnon, Troy - floated across the open space. Then the wind rose, and in the rustle of the leaves even the great words became inaudible; and the audience sat staring at the villagers, whose mouths opened, but no sound came. (BTA, 140)

While this disappearance of "great names" may imply that the historical dynamics could be reversed, the presentation of nature as the final instance which shapes history also articulates Woolf's mature pantheism, as convincingly argued by Madeline Moore. ${ }^{32}$ Nature is presented in the novel as a supreme power that may help as well as destroy our historical selves; at the same time nature is seen as abiding beyond history and ultimately uninterested in its agons and crises: beyond the sun withdrawing, "covering its face, as if it forbore to look on human suffering", beyond the clouds of current history, lacking "symmetry and order", far beyond earthly changes "variable winds" and "rain at times", there is - "pure blue" (BTA, 23). This unnamed (para)historical force is recognizable in Between the Acts as one of the natural phenomena or nature itself. Most frequently, however, it is simply a pattern, as argued in the contemporaneously written 'A Sketch of the Past': "From this I reach what I might call a philosophy (. . .); that behind the cotton wool is hidden a pattern; that we - I mean all human beings - are connected with this; that the whole world is a work of art; that we are parts of the work of art." ${ }^{\text {,3 }}$ For Woolf, the redemption of history as a nightmare inheres in the constellative activity of the (artistic) human subject itself, irrespective of causality and the subject's continued presence; it does so for Benjamin as well, but with one theological proviso: human activity is acknowledged only in the messianic constellation of the past and the present in which the subject is made aware that "every second [is] the small gateway in time through which the Messiah might enter" ("Concept”, 397).

\section{The Ethics of Writing History and Modernist Aesthetics}

The issues of pattern and historical engagement have finally led us to a hidden (and markedly intimate) concern informing Woolf's and Benjamin's reflections on history: the question of an ethical history-writing subject. The ideal history-writing subject, as seen by Benjamin and Woolf, engages with the past in such a way that he or she enacts at all times the dynamic triangulation of the past with the present and the future. In his <Paralipomena to "On the Concept of History" $>$, Benjamin writes that "the history-writing subject is, properly, that part of humanity whose solidarity embraces all the oppressed" (404). Comparably to Woolf's belief in the activity of the artist as engaged abstinent, Benjamin avers that such a writing-subject can "construct" a nonreactionary universal history, the one which would rely on a structural-constructive (and thus also artistic) principle [Konstruktiv]. "The structural principle of universal history", Benjamin proceeds, “allows [history] to be represented as partial histories", i.e. stories (404). This is why the messianic idea of history (by which we should understand history as shot through and narrated via this structural principle) coincides with the idea of prose, Benjamin closes laconically (404).

Whereas Benjamin's and Woolf's commitment to “read-write the unwritten” makes their respective projects akin to many contemporary and later philosophies of history, it is noteworthy 
that, with both authors, the prospective "constructive" historiography (new prose) requires more than a simple alteration of the topic: it calls for a thorough revision of the operative model of archiving, referencing, and interpreting, and thus also a substantial modification of the current epistemo-critical practice. This is the reason why their performative critiques of traditional historiography are directed specifically against linearity as a constructive principle of progressivism and teleology.

Since the historical narration is intrinsically prone to reification, to narrate history truthfully would mean to question the very process of narration while performing it, to invent such a mode of narration in which "the epic moment will always be blown apart in the process of construction" $(<$ Paralipomena $>$, 406). Such a mode of narration would require a continuous suspension of the epic nature of prose. Only such prose will honour "the memory of the anonymous" (406), Benjamin argues. Both Benjamin's commitment to fragmentary narration and the forceful elisions and fractures of the narrative in Woolf's Between the Acts, pointedly culminating in the peasants' song, perform this dedication to the memory of the anonymous. Indeed, Benjamin and Woolf propose remarkably similar performative responses to the question of writing history. In this context, some discursive similarities deserve to be noted. For instance, the syntax of both Benjamin's and Woolf's writings is characterized by the alteration of exuberance and minimalism. Marked by precision and subdued or overt irony, both discourses are surprisingly welded by redemptive, rhythmical passages with more than a hint of mysticism. This form then mimics the vacillation, rather than progression of the argument (or, in Woolf's case, the novel), thereby invoking formally the contentual critique of the linear conception of time, history, and argumentation.

On a deeper structural level, however, both Benjamin's "On the Concept of History” and Woolf's Between the Acts rely on a serial composition to exteriorise their implicit critiques of progressivism. While Benjamin's text belongs to the genre of 'theses' (especially with respect to its polemic character and its gesturing towards historical importance), it also re-evaluates this tradition in a properly modernist manner. Benjamin's theses takes the form of questions, aphorisms, and hypotheses, a form which, one may argue, resembles that of Kafka's aphoristicphilosophical miniatures. The linearity of this textual series is challenged in two ways: by breaking the narrative into images-fragments and by the montage-like constellation of these fragments, a technique which involves repetition, inversion, and convolution. These strategies exteriorise what the text contains: a critique of the concept of linear progression. For "history", Benjamin claims, "breaks down into images not into stories” ('N', p. 67-8). This performance corresponds to a compact set of definitions of what ('Benjaminian') historical materialism might be, offered in Convolute 11 of the Arcades Project:

Re the basic doctrine of historical materialism: 1) A historical object is whatever is redeemed by knowledge. 2) History breaks down into images, not into stories. 3) Wherever a dialectical process takes place, we are dealing with a monad. 4) The materialist presentation of history goes hand in hand with an immanent critique of the concept of progress. 5) The procedures of historical materialism are founded on experience, on common sense, on presence of mind, and on dialectics. ('N', 67-8)

These postulates suggest that Benjamin understands history as a modernist narrative event - a fragmentary juxtaposition of images rather than a seamless progression of stories. Since the discourse on history should mime the discourse of history, Benjamin proposes a history-writing practice that deals away with the concept of progress/progression: a dialectical reflection that singles out a historical event as a 'monad' rather than just a passing incident in the succession of historical changes. In this monad, a moment in the past and a moment in the present coalesce explosively, subverting the continuum of history and providing the historian with a theoretical and practical model for altering the present. And this is where Benjamin's text discloses its close structural correspondence to Woolf's last artistic cogitations on history.

In the context of Woolf's entire oeuvre, Between the Acts may strike one at first as a case of comparatively traditional (i.e., linear) story-telling. Yet a closer look reveals that, behind the appearance of a conventional narrative, the novel is replete with modal interlacing, subtle 
linguistic experimentation, and instances of generic hybridity. These poetic aberrations are grouped into sections (thirty-seven of them). Each section begins with a memorably delineated image (the parlour with the windows open to the garden and summer's night (Section 1; BTA, 3), nurses trundling the perambulator up and down the terrace (Section 2; 10), and on) which then unfolds and extends - temporally, but also cross- and extra-temporally. ${ }^{34}$ The opening section, the summer night scene in the Oliver household, is exemplary of this dynamics. The introductory image of a "big room with the windows open to the garden" at night (3) inaugurates a simultaneously historically specific and extra-temporal (and intertextual) chronotope that will memorably cast its shadow not only on this section but also on the entirety of the novel. This image-setting mentally extends into a specific site, chosen for the cesspool. The latter image is explicitly cast as a Benjaminian monad conjoining (involuntarily) the past and the present: "From an aeroplane, [Bart] said, you could still see, plainly marked, the scars made by the Britons; by the Romans, by the Elizabethan manor house; and by the plough” (4). Woolf invokes the scars from the Romans in order to indicate the present scars, those that the Second World War has inscribed; the latter are specified almost immediately by the introduction of Woolf's favoured marker of crisis/war in this novel - the image of the aeroplane. ${ }^{35}$ In this way, each section in Between the Acts acquires the status of an extended 'monadic' image, an aspect (trait) of which is subtly reinforced in the following or later episode. Thus each image-section interacts, peacefully or conflictingly, with other such images. The process takes different forms: repetition (e.g., the phrase "The laughter died away" which begins sections 14 and 15 (BTA, 58; 65)), inversion (Isa's 'outer' and 'inner' love in sections 3 and 4), contraposition/shifting of perspectives (Lucy's looking out of the window onto the garden in Section 2 is developed in reverse as a view from the garden in Section 3), convolution (the motif of the fish in sections 7 and 8), and others.

The effects of this compositional strategy are reinforced by a complex play of displaced and proper analogies and, as we have seen, Woolf's attempts narratively to perform the dynamics of agon and stasis. These narrative strategies indicate a comparable view of history as an agglomeration of images rather than a long and winding story, a vision of history that Woolf might have acquired only in the last years of her life. ${ }^{36}$ Between the Acts thus presents an extraordinary, perfectly timed (if never actually read at the time of its production) contribution to Benjamin's impossible project - at once to narrate and to question the narration of history.

This structural and thematic comparison and the recognition of Benjamin and Woolf's shared endorsement of "constructive principle” in history-writing/reading opens many other rewarding enquiries regarding the philosophy of history in the 1920s and the 1930s. At the same time, both Woolf and Benjamin gain something from this discursive juxtaposition: Woolf's mature aesthetic politics is placed where it should rightfully abide - in the realm of philosophy of history - and Benjamin's cogitations on history become actualized in aesthetic performance. Each serves as a corrective of the other, too: Woolf's gendering of philosophy of history productively reframes Benjamin's propositions; Benjamin's philosophical resuscitation of material history from and through the mythmaking activity reorients Woolf's own engagement with material history, superhistory, and the ways in which they are rendered. In effect, Benjamin helps us evaluate Woolf's epistemology and philosophy of history, as expounded in her essayistic prose and fiction in the late 1930s, and the understanding of Woolf's art becomes invaluable for our assessment of the position of aesthetic production in Benjamin's thought on history.

Finally, if the (re)articulation of history through narration is the primary potential of an ethical historical subject, then my project of interrelating Benjamin's and Woolf's philosophies of history - a mission that has only begun - should be understood as a performance in history, too. By invoking a constellation that has escaped the record and registering its contents as well as its lacunae, one enters the action-field of history.

\section{Notes}

${ }^{1}$ Walter Benjamin, Gesammelte Briefe (henceforth GB), eds. Christoph Godde and Henri Lonitz, 6
vols. (Frankfurt: Suhrkamp, 2000), vol. VI, 379. On Benjamin’s last years in France, see Ingrid 
Scheurmann, “Als Deutscher in Frankreich: Walter Benjamins Exil, 1933-1940”, Für Walter Benjamin, eds. Ingrid Scheurmann and Konrad Scheurmann (Frankfurt: Suhrkamp, 1992), 75-113.

2 The Letters of Virginia Woolf, ed. Nigel Nicolson and Joanne Trautmann, 6 vols. (London: The Hogarth Press, 1980; henceforth Letters), vol. VI, 379.

${ }^{3}$ The Diary of Virginia Woolf, ed. Anne Olivier Bell, assisted by Andrew McNeillie, 5 vols. (San Diego, New York, and London: Harvest Book and Harcourt Brace Jovanovich, 1977-1984; henceforth Diary), vol. V, 285.

${ }^{4}$ In my discussion of the two works I will be referring to the following editions: Virginia Woolf, Between the Acts [1941] (San Diego, New York, and London: Harvest Book and Harcourt Brace Jovanovich, 1970), henceforth appearing parenthetically in the text in its standard abbreviation BTA, and Walter Benjamin, "On the Concept of History", Selected Writings (henceforth SW and 'Concept'), eds. Howard Eiland and Michael W. Jennings, trans. Edmund Jephcott and others, 4 vols. (Cambridge, Mass.: Harvard University Press, 1996-2003), vol. IV, 389-400; and, the German original of Benjamin's text in Walter Benjamin, "Über den Begriff der Geschichte", Gesammelte Schriften (GS), eds. Rolf Tiedemann and Hermann Schweppenhäuser (Frankfurt: Suhrkamp, 1974-1989), vol. I/2, 693-703.

${ }^{5}$ Benjamin wrote "On the Concept of History” from February to May 1940, but the preparatory work on the text probably began already in 1938, since the theses were derived from Benjamin's 1937 assessment of historiography in “Eduard Fuchs, Collector and Historian”. Benjamin’s “On the Concept of History" remained unpublished in his lifetime because the author believed that a premature publication would open the door to "enthusiastic misunderstanding" (GB, vol. VI, 436). Woolf began working on Between the Acts before April 12, 1938 (the date of the first reference to the novel) and completed the last revision of her manuscript on February 26, 1941. In her last letter to John Lehmann, Woolf withdrew Between the Acts from publication, arguing that the text was trivial and sketchy (Letters, vol. VI, 486).

${ }^{6}$ For recent accounts of Benjamin's thought on history, see, Walter Benjamin and the Demands of History, ed. Michael P. Steinberg (Ithaca: Cornell University Press, 1996), and Beatrice Hanssen, Walter Benjamin's Other History: Of Stones, Animals, Human Beings, and Angels (Berkeley: University of California Press, 1998). For the position of Benjamin's 'materialist-theological' concept of history within the context of the Frankfurt School philosophies of history, see, among others, Rolf Tiedemann, Studien zur Philosophie Walter Benjamins (Frankfurt: Europäische Verlagsanstalt, 1965) and Martin Jay, The Dialectical Imagination: A History of the Frankfurt School and the Institute of Social Research (Boston: Little, Brown, 1973). On Woolf's discussion of material history in her fiction and essays, see, in particular, Alex Zwerdling, Virginia Woolf and the Real World (Berkeley and Los Angeles: University of California Press, 1987); for the development of Woolf's concept of history out of her 'war consciousness', see, Virginia Woolf and the War: Fiction, Reality, and Myth, ed. Mark Hussey (Syracuse: Syracuse University Press, 1991) and Karen L. Levenback, Virginia Woolf and the Great War (Syracuse: Syracuse University Press, 1999); finally, for a rare attempt to analyse Woolf's concept of history in the light of contemporary intellectual and philosophical practice, see Sabine Hotho-Jackson, "Virginia Woolf on History: Between Tradition and Modernity", Forum for Modern Language Studies, 27/4 (1991): 293-313.

${ }^{7}$ See Rachel Bowlby, "Walking, Women and Writing: Virginia Woolf as flâneuse”, in Still Crazy After All These Years: Women, Writing and Psychoanalysis (London: Routledge, 1992), 1-34, and Deborah Parsons, Streetwalking the Metropolis: Women, the City and Modernity (Oxford: Oxford University Press, 2000). 
${ }^{8}$ Virginia Woolf in the Age of Mechanical Reproduction, ed. Pamela Caughie (London and New York: Garland, 2000); Makiko Minow-Pinkney, "The Meaning on the Far Side of Language: Walter Benjamin's Translation Theory and Virginia Woolf's Modernism”, in Woolf Across Cultures, ed. Natalya Reinhold (New York: Pace University Press, 2004), 79-94.

9 Marie-Luise Gättens, Women Writers and Fascism: Reconstructing History (Gainesville, FL: University Press of Florida, 1995). Gättens's book is a study of different ways in which the postSecond World War German women writers, such as Helga Schubert, Christa Wolf, and others, responded to the legacy of German fascism.

${ }^{10}$ It would be beyond the scope of the present essay to re-relate the considerable historical data and discussions relevant to the multiple crises that marked the political and intellectual history of modernism. For the general and intellectual history of the period, the reader is advised to consult a useful overview-type volume such as Peter Childs’s Modernism (London: Routledge, 2000).

11 Jacques-Émile Blanche, “Entretien avec Virginia Woolf”, Les nouvelles littéraires (Paris, 13 Aug 1927): 1-2; Virginia Woolf, Mrs. Dalloway, trans. S. David, pref. André Maurois (Paris: Delamain et Boutelleau, 1929); Floris Delattre, Le Roman psychologique de V. Woolf (Paris: Vrin, 1932); Virginia Woolf, Les Vagues, trans. and pref. Marguerite Yourcenar (Paris: Stock, 1937).

${ }^{12}$ Beach and Monnier showed their friendly support in particular in the late 1930s. The two female intellectuals provided Benjamin with books, chocolates and cigarettes during the period of his detention (September - November 1939) and Monnier was instrumental in Benjamin's eventual release (SW, 439). For an account of Benjamin's stay in the French internment camp, and Beach's and Monnier's help, see Hans Sahl, "Walter Benjamin in the Internment Camp”, trans. Deborah Johnson, in On Walter Benjamin, ed. Gary Smith (Cambridge, Mass.: MIT Press, 1988), especially 348-350.

13 Bertolt Brecht's The Threepenny Opera premiered on 31 August 1928 at the Theater am Schiffbauerdamm and Auden went to see the play immediately upon his arrival in Berlin in October 1928. See Norman Page, Auden and Isherwood: The Berlin Years (New York: St. Martin’s Press, 1998), 83.

${ }^{14}$ Brecht and Benjamin first met in November 1924, but it was not until their meeting in Berlin in May 1929 that their active collaboration and intellectual exchange began. For an extensive, biographically-based account of Brecht's and Benjamin's friendship and their various professional collaborations, see Erdmut Wizisla, Benjamin und Brecht. Die Geschichte einer Freundschaft. Mit einer Chronik und den Gesprächsprotokollen des Zeitschriftenprojekts 'Krise und Kritik' (Frankfurt: Suhrkamp 2004). On Benjamin's early philosophy of history and his development as a political thinker in the late 1920s and early 1930s, see Uwe Steiner, "The True Politician: Walter Benjamin's Concept of the Political”, New German Critique 83 (Spring-Summer 2001): 39-64; in particular 45-60.

${ }^{15}$ The last two sections appear in early drafts, but are excluded from the final versions. While their status remains unclear, they are generally printed as a supplemental "ending" of the text, on account of their conclusive nature and intrinsic interest. Cf. SW, 397; 400 (n. 28); and, GS, 703; 1252-59.

${ }^{16}$ The list of sources that contributed to the fruition of Benjamin's thought on history is long and contradictory, and includes figures such as Ernst Bloch, Bertolt Brecht, Jacob Burckhardt, Sigmund Freud, Martin Heidegger, Ernst Jünger, Georg Lukács, Karl Marx, Heinrich Rickert, Carl Schmitt, Georges Sorel, and many others. For general discussions of Benjamin's interaction with intellectual currents in philosophy of history, see, Liselotte Wiesenthal, Zur Wissenschaftstheorie Walter Benjamins (Frankfurt: Vertelsmann, 1973); John McCole, Walter Benjamin and the 
Antinomies of Tradition (Ithaca: Cornell University Press, 1993); and Gérard Raulet, Le caractére destructuer. Esthétique, théologie et politique chez Walter Benjamin (Paris: Aubier, 1997).

${ }^{17}$ See Benjamin's letter to Gretel Adorno, GB, vol. VI, 435. See also the editors' commentary in SW, 440-41.

${ }^{18}$ Virginia Woolf, Between the Acts [1941] (San Diego, New York, and London: Harvest Book and Harcourt Brace Jovanovich, 1970), 114.

${ }^{19}$ Heinz-Dieter Kittsteiner, "The Allegory of the Philosophy of History in the Nineteenth Century”, in Walter Benjamin and the Demands of History, 60.

${ }^{20}$ On Benjamin as a critic of cultural history, see Irving Wohlfarth, "Smashing the Kaleidoscope: Walter Benjamin's Critique of Cultural History", in Walter Benjamin and the Demands of History, 190-205. On the Cambridge Apostles' substantial influence on Bloomsbury writers, see S. P. Rosenbaum, Victorian Bloomsbury: The Early Literary History of the Bloomsbury Group (New York: St. Martin's Press, 1987), vol. 1, 161-238, and Ann Banfield, The Phantom Table: Woolf, Fry, Russell, and the Epistemology of Modernism (Cambridge: Cambridge University Press, 2000), 1-55.

${ }^{21}$ See, for one, Harvena Richter, Virginia Woolf: The Inward Voyage (Princeton: Princeton UP, 1970).

${ }^{22}$ See R. G. Collingwood, "History as Re-enactment of Past Experience”, in Theories of History ed. Patrick Gardiner (New York and London: 1959), 253, et passim.

${ }^{23}$ Theodor W. Adorno, Minima Moralia (London: New Left Books, 1974), 151.

${ }^{24}$ See Beatrice Hanssen, Walter Benjamin’s Other History.

${ }^{25}$ Rodolphe Gasché, "Saturnine Vision and the Question of Difference in Walter Benjamin's Theory of Language”, Benjamin's Ground: New Readings of Walter Benjamin, ed. Rainer Nägele (Detroit: Wayne State University Press, 1989), 100.

${ }^{26}$ Diary, vol. III, 37.

${ }^{27}$ Cf., Benjamin's response to Max Horkheimer's critique of this temporal inconsistency in the Arcades Project: "history is not just a science but also a form of memoration [remembrance, eine Form des Eingedenkens]." See " $\mathrm{N}$ [Re the Theory of Knowledge, Theory of Progress]", in Benjamin: Philosophy, Aesthetics, History, ed. Gary Smith (Chicago: University of Chicago Press, 1989), 61.

${ }^{28}$ This strategy entails a unique wielding of temporality, which found its expression in the conception of time proposed in the messianic closure of Benjamin's "Concept". For many scholars, this wielding of temporality is the major methodological inconsistency in Benjamin's thought: having directed our attention to the harshness of past injustices, the thinker proposes to amend, indeed "redeem" them in eschatological time.

${ }^{29}$ Gillian Beer has also noted that Woolf's fusion of (prehistoric) past and present results in temporal stasis. She has inferred that history for Woolf was a game, a "playful spume of language" (Gillian Beer, "Virginia Woolf and Pre-History", Virginia Woolf: A Centenary Perspective, ed. Eric Warner (London: Macmillan, 1984), 102). Beer's argument is perceptive, especially with regard to the relation between Woolf's vision of history and the ludic mode of Between the Acts. However, the pre-narrative, or, to be more precise, pre-epic drive of the novel can be read 
differently, if reflected through a philosophy of history that was contemporary to Woolf's text. Reread in the context of the moment of its production, Between the Acts is revealed as a compelling manifestation of Woolf's conceptualisation of historical engagement in the late 1930s.

${ }^{30}$ See Banfield, The Phantom Table, 213-241.

${ }^{31}$ Virginia Woolf, Three Guineas (London: Hogarth, 1938), 85.

32 See Madeline Moore, The Short Season Between Two Silences: The Mystical and the Political in the Novels of Virginia Woolf (Boston: George Allen \& Unwin, 1984).

${ }^{33}$ Virginia Woolf, Moments of Being, ed. Jeanne Schulkind (New York and London: Harcourt Brace Jovanovich, 1976), 119.

34 These images-sections are occasionally further dissected into subsections, sub-images, which may interrelate peacefully or clash, or establish connections with other sections-images. In this respect, the most productive part of the text is Miss La Trobe's pageant.

${ }^{35}$ On the ambivalent symbolism of the aeroplane and its contribution to the figuration of the new historical subject in Woolf, see, Gillian Beer, "The Island and the Aeroplane: The Case of Virginia Woolf”, in Nation and Narration, ed. Homi K. Bhabha (London and New York: Routledge, 1990), 265-290.

${ }^{36}$ Here I disagree with Hotho-Jackson, who proposes that Woolf perceives history "traditionally" as a story. While Woolf is attentive to the narrative potential of history, she is also much aware of the fragmentary and image-like nature of this "story". 